\title{
COMPARATIVE STUDY OF THE POST OPERATIVE ANALGESIC EFFECT OF CAUDAL BLOCK WITH ILIOINGUINAL NERVE BLOCK USING BUPIVACAINE IN CHILDREN 2-7 YEARS OLD UNDERGOING BELOW UMBILICAL SURGERIES
}

\author{
Gilakala Varaha Ganesh ${ }^{1}$, Penmetsa Usha Rani², Ravali Sade 3
}

${ }^{1}$ Associate Professor, Department of Anaesthesiology, King George Hospital, Visakhapatnam, Andhra Pradesh.

${ }^{2}$ Assistant Professor, Department of Anaesthesiology, King George Hospital, Visakhapatnam, Andhra Pradesh.

${ }_{3}^{3}$ Postgraduate Student, Department of Anaesthesiology, King George Hospital, Visakhapatnam, Andhra Pradesh.

ABSTRACT

\section{BACKGROUND}

Pain control, especially among paediatric age group is important for decreasing morbidity and mortality. Regional anaesthesia produces excellent post-operative analgesia and attenuation of the stress responses in children. Caudal anaesthesia is the oldest and still most commonly used technique of epidural blockade in children undergoing surgical procedure in lower part of body. Further, the ilio-inguinal nerve block provides excellent pain relief for operations in the inguinal region.

The aim of this study was to compare the post-operative analgesic effect of caudal block with ilioinguinal block using bupivacaine in children 2-7 years old undergoing below umbilical surgeries.

\section{MATERIALS AND METHODS}

It was a non-randomized control trial study, conducted at King George Hospital, Visakhapatnam, with approval from Institutional Ethics Committee, during the period of June 2017 to October 2018, among 40, 2-7 years old children of both sexes belonging to American Society of Anaesthesiologists (ASA) physical status 2 and 3, scheduled for elective inguinal surgeries under general anaesthesia. They were equally designated to Group A and Group B who received $0.25 \%$ caudal block with $0.75 \mathrm{ml} / \mathrm{kg}$ bupivacaine $0.25 \%$ and ilioinguinal block with $0.3 \mathrm{ml} / \mathrm{kg}$ bupivacaine $0.25 \%$, respectively, and were assessed by objective pain scale. The sample size was taken at conveniences.

\section{RESULTS}

The objective pain scale following both ilioinguinal block and caudal block was compared and found that the difference between the two groups was not significant.

\section{CONCLUSION}

In this study, ilioinguinal nerve block was as effective as caudal regarding the quality and duration of postoperative analgesia.

\section{KEY WORDS}

Caudal Block, Ilioinguinal Nerve Block

HOW TO CITE THIS ARTICLE: Ganesh GV, Rani PU, Sade R. Comparative study of the post-operative analgesic effect of caudal block with ilioinguinal nerve block using bupivacaine in children 2-7 years old undergoing below umbilical surgeries. J. Evolution Med. Dent. Sci. 2019;8(08):532-534, DOI: 10.14260/jemds/2019/117

\section{BACKGROUND}

- $\quad$ Pain is defined as "unpleasant sensory and emotional experience associated with actual or potential tissue damage or described in terms of such damage. ${ }^{1}$

- $\quad$ Control of post-operative pain is important in paediatric patients because poor pain control may result in increased morbidity or mortality.

- Historically, children have been untreated for pain and painful procedures.

- An unproved safety and efficacy of the analgesics and worries about the risk of opioid induced respiratory depression, added more reasons for the under treatment of pain in children. ${ }^{2}$

'Financial or Other Competing Interest': None.

Submission 30-11-2018, Peer Review 08-02-2019,

Acceptance 16-02-2019, Published 25-02-2019.

Corresponding Author:

Penmetsa Usha Rani,

Flat No. 201, Leela Residency, Murali Nagar

Above Bank of Maharashtra, Bank Street,

Visakhapatnam, Andhra Pradesh,

India.

E-mail: doctorraju@yahoo.com

DOI: $10.14260 /$ jemds/2019/117
- Under treatment of post-operative pain in children may trigger biochemical and physiologic stress response and cause impairment in pulmonary, cardiovascular, neuro endocrinal, gastrointestinal, immunological and metabolic functions.

- Regional anaesthesia produces excellent post-operative analgesia and attenuation of the stress responses in children.

- Caudal anaesthesia is the most commonly used technique of epidural blockade in children recommended for most surgical procedures of the lower part of the body. ${ }^{3}$

- The ilioinguinal nerve block provides excellent pain relief for operations on the inguinal region. 4

- In this study we compared the effect of caudal anaesthesia and ilioinguinal nerve block on postoperative analgesia using bupivacaine.

\section{Aims and Objectives}

Aim

- This study was designed to compare the post-operative analgesic effect of caudal block with ilioinguinal block using bupivacaine in children 2-7 years old undergoing below umbilical surgeries. 


\section{Objectives}

- To describe the benefits of caudal block and ilioinguinal block.

- $\quad$ Post-Operative pain scores: Objective Pain Scale (OPS).

- $\quad$ Surgery time, Basic Heart Rate, Basic SBP, Basic DBP.

- Modified Bromage scale to evaluate for motor blockade.

\section{MATERIALS AND METHODS}

- It was a non-randomized control trial study, conducted at king George Hospital, Visakhapatnam, with approval from Institutional Ethics Committee, among 40 patients, 2-7 years old children of both sexes belonging to American society of Anaesthesiologists (ASA) physical status 1 and 2, scheduled for elective inguinal surgeries under general anaesthesia.

- They were equally designated to Group A and Group B in which Group A received caudal block with $0.75 \mathrm{ml} / \mathrm{kg}$ of $0.25 \%$ bupivacaine and Group B received ilioinguinal block with $0.3 \mathrm{ml} / \mathrm{kg}$ of $0.25 \%$ bupivacaine, and were assessed by objective pain scale.

\section{Inclusion Criteria}

1. Age group 2-7 years.

2. American Society of Anesthesiologist (ASA) status II and III.

3. Patients scheduled for elective inguinal surgeries.

\section{Exclusion Criteria}

1. Emergency Cases.

2. Known allergy to any of the drugs used in the study.

3. Contra indications to caudal and ilioinguinal black including.

a. Infection at site.

b. Pilonidal cyst.

c. Coagulopathies.

d. Congenital anomaly of spine or meninges.

4. Patient refusal.

- After premedication with $0.03 \mathrm{mg} / \mathrm{kg}$ intravenous midazolam, general anaesthesia was induced with 1 $\mathrm{mg} / \mathrm{kg}$ fentanyl, and $3 \mathrm{mg} / \mathrm{kg}$ propofol.

- Anaesthesia was maintained with $1-1.5 \%$ isoflurane in $\mathrm{O}_{2} / \mathrm{N}_{2} \mathrm{O}$

- Infusion of $2.5 \%$ dextrose in Ringer $(10 \mathrm{ml} / \mathrm{kg})$ was given

- Caudal block was performed with the child in the left lateral decubitus position.

- After insertion of a 23 Gauge needle into caudal epidural space and negative aspiration for blood and cerebrospinal fluid, $0.75 \mathrm{ml} / \mathrm{kg}$ of $0.25 \%$ bupivacaine was injected.

- The ilioinguinal nerve block was performed by insertion of a short bevelled needle at the junction of lateral $1 / 4$ and medial $3 / 4$ on the line drawn between anterior superior iliac spine and umbilicus.

- The needle should initially inserted perpendicular to the skin, then declined to $45^{\circ}-60^{\circ}$ directed to the middle of the inguinal ligament, then slowly advanced until the aponeurosis of the external oblique muscle was traversed.

- $\quad 0.3 \mathrm{ml} / \mathrm{kg}$ of $0.25 \%$ bupivacaine was injected.
- Heart rate, non-invasive blood pressure and peripheral oxygen saturation $\left(\mathrm{SpO}_{2}\right)$ was recorded every 5 mins. intra-operatively and every $5 \mathrm{~min}$ in recovery room for one hour.

- After the surgery, the patients were transferred to the recovery room when they were sufficiently awake and capable of maintaining open airway.

- Post-operative analgesia was assessed by objective pain scale (OPS).

- This scale is composed of five parameters:

- Crying.

- Movement.

- Agitation.

- Blood pressure.

- Verbal Complaints of pain.

- Each parameter is attributed a value between 0 \& 2 with total values between 0 $\& 10$

- If the result of the evaluation was 0 , it indicates absence of pain

- $\quad$ Between $1 \& 3$ - Mild pain and the child does not need analgesics

- Between $4 \& 6$ - Moderate pain and the child requires analgesics

\section{Between 7 \& 10- Severe Pain}

- Modified Bromage scale - to evaluate for motor blockade.

- Values between 0 \& 3 -

- 0 - Absence of motor blockade.

- 3 - Complete motor blockade.

- Pain was evaluated every hour.

- The degree of motor blockade was evaluated every hour.

- Surgery time, Basic Heart, Basic SBP, Basic DBP were recorded in both the groups, the sample size was taken conveniences.

\section{Statistical Analysis}

Statistical analysis was done using SPSS Version 16.0. Chisquare test or Fisher's test was applied to compare means of Kujala score at different phases.

\section{RESULTS}

\begin{tabular}{|l|l|l|}
\hline \multicolumn{1}{|c|}{ Parameters } & \multicolumn{1}{|c|}{ Group A } & \multicolumn{1}{c|}{ Group B } \\
\hline $\begin{array}{l}\text { Age } \\
\text { Weight }\end{array}$ & $5.4 \pm 4.5$ & $4.5 \pm 2.03$ \\
\hline $\begin{array}{l}\text { Male / Female } \\
\text { Duration of surgery } \\
\text { (min) }\end{array}$ & $13.55 \pm 3.9$ & $13.89 \pm 5.01$ \\
\hline $\begin{array}{l}\text { Basal Heart Rate } \\
\text { (BPM) }\end{array}$ & $101.3 \pm 5.4$ & $18 / 2$ \\
\hline $\begin{array}{l}\text { Basal systolic blood } \\
\text { pressure }\end{array}$ & $85.5 \pm 6.04$ & $86.5 \pm 7.45 \pm 7.6$ \\
$\begin{array}{l}\text { Basal diastolic } \\
\text { blood pressure }\end{array}$ & $57.15 \pm 4.5$ & $56 \pm 5.02$ \\
\hline \multicolumn{2}{|l|}{ Table 1. Demographic Details of The Study Population } \\
\hline
\end{tabular}


The objective pain scale following both ilioinguinal block and caudal block was compared and found that the difference between the two groups was not significant. (Chi-square test value $=2.02$ )

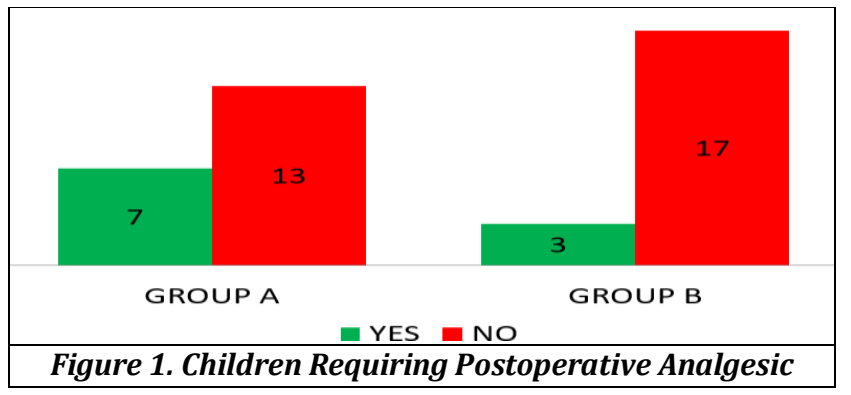

7 out of 20 patients i.e., $35 \%$ in Group A required post op analgesia while 3 out of 20 patients i.e., 15\% in Group B required post op analgesia at the end of $3 \mathrm{hrs}$.

- The two groups were compared using Chi-square test.

\section{DISCUSSION}

- Using Chi-square test we found both techniques were effective in reducing pain and there was no significant difference between two groups statistically.

- After induction of general anaesthesia caudal epidural block is widely used to provide Post-operative pain relief following below umbilical 3 surgeries in children .Ilioinguinal nerve block for the relief of post-operative pain has also been advocated as a safe technique for providing post-operative analgesia in children by Shandling 5 and Stewart 1980 and Smith and Jones 1982.

- Caetano et al.6 found caudal epidural and ilioinguinal nerve block were comparable in postoperative analgesia in children undergoing inguinal herniorrhaphy.

- Hannallah et al7 proved that there is no difference in the postoperative analgesic effects between caudal block and ilioinguinal block post orchidorrhaphy.

- QuentinA Fisheret al ${ }^{8}$ noted that using $0.25 \%$ bupivacaine $0.4 \mathrm{ml} / \mathrm{kg}, 74 \%$ of the patients were free at 4 hours .In the present siudy $86 \%$ of the patients had total pain relief at the end of 4 hours. This study concurs with the studies of Quentin A Fisher et al.

- The relief of pain during post-operative period has been of great interest to mankind down the ages. Mather $\mathrm{L}$ ,Mackie-J-et al. 9 in 1983 reported that $40 \%$ of Paediatric patients experienced moderate to severe Post-operative pain and that $75 \%$ had insufficient analgesia.
- S.J. Markham et al,10 compared the quality of analgesia provided by caudal block and peripheral nerve block using $0.5 \%$ bupivacaine in children undergoing herniotomy under general anaesthesia. Complications like used in higher concentration is associated with motor blockade. Hence in our study, we used $0.25 \%$ Bupivacaine.

\section{CONCLUSION}

In this study, ilioinguinal nerve block was as effective as caudal with regard to the quality and duration of postoperative analgesia.

\section{REFERENCES}

[1] International Association for the Study of Pain (IASP). Pain terms: a list with definitions and notes on usage. Recommended by the IASP Subcommittee on Taxonomy. Pain 1979;6(3):249-51.

[2] Lönnqvist PA, Morton NS. Postoperative analgesia in infants and children. Br J Anaesth 2005;95(1):59-68.

[3] Wolf AR, Valley RD, Fear DW, et al. Bupivacaine for caudal analgesia in infants and children: the optimal effective concentration. Anaesthesiology 1988;69(1):102-6.

[4] Somri M, Gaitini LA, Vaida SJ, et al. Effect of ilioinguinal nerve block on the catecholamine plasma levels in orchidopexy: comparison with caudal epidural block. Paediatric Anaesth 2002;12(9):791-7.

[5] Shandling B, Steward DJ. Regional analgesia for postoperative pain in paediatric outpatient surgery. Journal of Paediatric Surgery 1980;15(4):477-80.

[6] Caetano AM, Falbo GH, Lima LC. Comparison among three techniques of postoperative regional analgesia with ropivacaine in children. Rev Bras Anestesiol 2006;56(6):561-70.

[7] Hannallah RS, Broadman LM, Belman AB, et al. Comparison of caudal and ilioinguinal/iliohypogastric nerve blocks for control of post-orchidopexy pain in pediatric ambulatory surgery. Anaesthesiology 1987;66(6):832-4.

[8] Fisher QA, McComiskey CM, Hill JL, et al. Postoperative voiding interval and duration of analgesia following peripheral or caudal nerve blocks in children. Anesth Analg 1993;76(1):173-7.

[9] Mather L, Mackie J. The incidence of postoperative pain in children. Pain 1983;15(3):271-82.

[10] Markham SJ, Tomilnson J, Hain WR. Llioinguinal nerve block in children. A comparison with caudal block for intra and postoperative analgesia. Anaesthesia 1986;41(11):1098-103. 